\title{
Grain-Boundary Physics in Polycrystalline Photovoltaic Materials
}

Conference Paper NREL/CP-520-42510

May 2008

\section{Preprint}

Y. Yan, C.S. Jiang, X.Z. Wu, R. Noufi, S.H. Wei, and M.M. Al-Jassim

National Renewable Energy Laboratory

Presented at the 33rd IEEE Photovoltaic Specialists Conference San Diego, California May 11-16, 2008 


\section{NOTICE}

The submitted manuscript has been offered by an employee of the Midwest Research Institute (MRI), a contractor of the US Government under Contract No. DE-AC36-99G010337. Accordingly, the US Government and MRI retain a nonexclusive royalty-free license to publish or reproduce the published form of this contribution, or allow others to do so, for US Government purposes.

This report was prepared as an account of work sponsored by an agency of the United States government. Neither the United States government nor any agency thereof, nor any of their employees, makes any warranty, express or implied, or assumes any legal liability or responsibility for the accuracy, completeness, or usefulness of any information, apparatus, product, or process disclosed, or represents that its use would not infringe privately owned rights. Reference herein to any specific commercial product, process, or service by trade name, trademark, manufacturer, or otherwise does not necessarily constitute or imply its endorsement, recommendation, or favoring by the United States government or any agency thereof. The views and opinions of authors expressed herein do not necessarily state or reflect those of the United States government or any agency thereof.

Available electronically at http://www.osti.gov/bridge

Available for a processing fee to U.S. Department of Energy and its contractors, in paper, from:

U.S. Department of Energy

Office of Scientific and Technical Information

P.O. Box 62

Oak Ridge, TN 37831-0062

phone: 865.576 .8401

fax: 865.576 .5728

email: mailto:reports@adonis.osti.gov

Available for sale to the public, in paper, from:

U.S. Department of Commerce

National Technical Information Service

5285 Port Royal Road

Springfield, VA 22161

phone: 800.553 .6847

fax: 703.605.6900

email: orders@ntis.fedworld.gov

online ordering: http://www.ntis.gov/ordering.htm 


\title{
GRAIN-BOUNDARY PHYSICS IN POLYCRYSTALLINE PHOTOVOLTAIC MATERIALS
}

\author{
Yanfa Yan, C.S. Jiang, X.Z. Wu, R. Noufi, S.-H. Wei, and M.M. Al-Jassim \\ National Renewable Energy Laboratory, 1617 Cole Blvd., Golden, CO 80401, USA
}

\begin{abstract}
We use the combination of high-resolution electron microscopy and density-functional theory to study the atomic structure and electronic effects of grain boundaries in polycrystalline photovoltaic materials such as $\mathrm{Si}$, CdTe, $\mathrm{CuInSe}_{2}$, and $\mathrm{CuGaSe}_{2}$. We find that grain boundaries containing dislocation cores create deep levels in Si, $\mathrm{CdTe}$, and $\mathrm{CuGaSe}_{2}$. Surprisingly, however, they do not create deep levels in $\mathrm{CulnSe}_{2}$. We further find that the presence of $\mathrm{Ga}$ in grain boundaries in $\mathrm{CulnSe}_{2}$ generates deep levels. These results may explain the fact that $\mathrm{Si}$ and CdTe solar cells usually require special passivation, whereas $\mathrm{CulnSe}_{2}$ solar cells do not. The passivation of grain boundaries in $\mathrm{Si}$ and $\mathrm{CdTe}$ is also studied. We find that grain boundaries in CdTe can be passivated very well by $\mathrm{Cl}, \mathrm{Br}$, and I.
\end{abstract}

\section{INTRODUCTION}

Polycrystalline semiconductor materials, such as $\mathrm{Si}$, $\mathrm{CdTe}$, and $\mathrm{CuInSe}_{2}$ (CIS), hold great promise for producing low-cost, high-efficiency, and large-area solar cells [1-3]. However, polycrystalline materials are typically expected to exhibit poor performance compared to their single-crystalline counterparts [4], because of grain boundaries, which are usually effective recombination centers for photon-generated electrons and holes, as well as scattering centers of free carriers. Therefore, passivation is usually required for making high-efficiency $\mathrm{Si}$ and CdTe solar cells [1,2]. However, CIS is an exception. Without special grain-boundary (GB) passivation, the efficiency of the polycrystalline $\mathrm{Cu}(\mathrm{In}, \mathrm{Ga}) \mathrm{Se}_{2}$ (CIGS)-based device is now approaching $20 \%$ [3], significantly surpassing the best corresponding single-crystal devices ( 13\%) [5]. CuGaSe 2 (CGS) has the same structure as CIS. However, CGS solar cells have much lower performance than CIS cells. The classic "electronic" GB model concludes that GBs in polycrystalline semiconductors usually contain charged intrinsic defects that trap an excess number of majority carriers and form electrical potentials [6]. In the past, several scenarios were also presented to explain the behavior of $\mathrm{GBs}$ in $\mathrm{CIS}$, but they are still under debate $[7,8]$. Therefore, there is still a need to understand the GB physics in photovoltaic materials.

Here, we use the combination of high-resolution electron microscopy and first-principles calculations to determine the atomic structure of grain boundaries and calculate the electronic properties of the following photovoltaic materials: Si, CdTe, CIS, and CGS. We found that GBs in Si, CdTe, and CGS create deep levels and belong to the conventional GB model-the "electronic model." However, GBs in CIS do not create deep levels and are electrically benign [10]. Our results explain why CIS solar cells do not require a special passivation process, and we propose that high $\mathrm{Ga}$ concentration of $\mathrm{Ga}$ in CIGS grain boundaries are not desired. Our results also indicate that GBs in Si can only be partially passivated. However, GBs in polycrystalline CdTe are well passivated by $\mathrm{Cl}$ and I impurities.

\section{METHOD}

Transmission electron microscopy (TEM) specimens were prepared by mechanical polishing to a thickness of $\sim 100 \mu \mathrm{m}$, then dimpling the central portion of the specimens down to $\sim 5 \mu \mathrm{m}$. The samples were subsequently thinned to electron transparency using a 4$\mathrm{kV} \mathrm{Ar}$ ion beam at $14^{\circ}$ inclination, then cleaned at a lower voltage $(1.5 \mathrm{kV})$. A liquid $\mathrm{N}_{2}$ cooling stage was used to minimize milling damage. High-resolution TEM (HRTEM) images were taken on a Philips CM30 microscope with a $\mathrm{Cs}=2.0 \mathrm{~mm}$, operating at $300 \mathrm{kV}$. The image simulations were carried out using the MacTempas program packages.

The first-principles total-energy calculations are based on the density-functional theory, using the Vienna ab-initio Simulation Package (VASP) [11]. We used the local density approximation (LDA) and ultrasoft Vanderbilt-type pseudopotentials [12] as supplied by Kresse and Hafner [13]. The cutoff energy for the plane-wave basis was 380 $\mathrm{eV}$. The GBs were modeled using a 144-host-atom supercell. In all calculations, all atoms were allowed to relax to reach the minimum energies until the HellmannFeynman forces acting on them became less than 0.02 eVIÅ.

\section{RESULTS AND DISCUSSION}

We first determined the atomic structure of $\mathrm{GBs}$ in $\mathrm{Si}$, CdTe, CIS, and CGS. It is usually very difficult to determine atomic structure of GBs in polycrystalline thin films. However, Si, CdTe, CIS, and CIGS have similar cubic crystal structures that can be described from the basic diamond structure. Si has a diamond structure that can be described by stacking Si layers along the [111] direction. CdTe can be described in the same manner, but with alternating $\mathrm{Cd}$ and Te layers. CIS can be described by alternately stacking a Se layer and a mixed $\mathrm{Cu}$ and In layer. Thus, it is reasonable to assume that GBs with the same characteristics should have the same atomic structure. We were only able to determine experimentally 
the atomic structure GBs in polycrystalline CdTe thin films. We will adopt the structure for the defects in $\mathrm{Si}, \mathrm{CIS}$, and CGS for density-functional theory calculations.

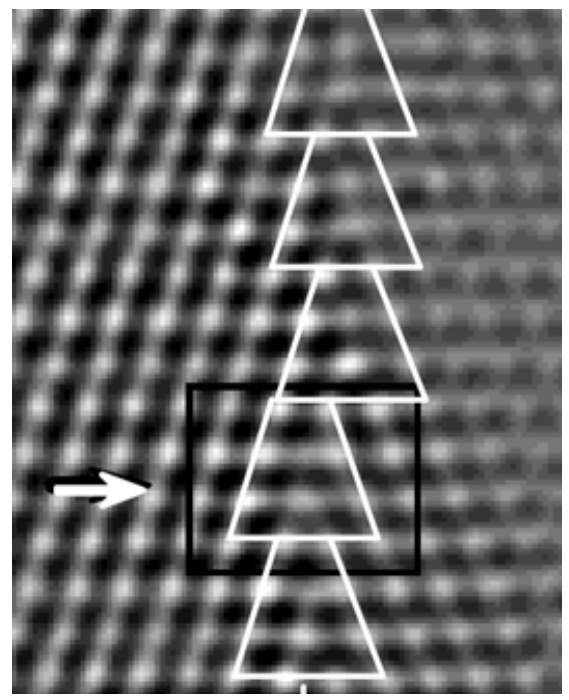

Fig. 1. HRTEM image of a GB in CdTe.

Figure 1 shows a HRTEM image of a GB obtained in a polycrystalline CdTe thin film. The GB consists of dislocation cores, as indicated by the white trapezoids. The GB is on the (11-2) plane. Based on the HRTEM image, eight possible structural models for the DP twin boundary are constructed with the guidance of the HRTEM image. These structure models are then relaxed using first-principles density-functional total-energy calculations. We find that there are only two structures that remain stable after the relaxation. Their optimized structures are shown in Figs. 2(a) and 2(b). The blue (dark color) balls indicate $\mathrm{Cd}$ atoms, whereas the gray (light color) balls indicate Te atoms. These two structures, called GB1 and GB2, respectively, look similar, but have different details. For example, in GB1, in Fig. 2(a), the atom numbered by 3 has four bonds and Te numbered by 2 has a dangling bond. But in GB2, the atom numbered by 3 has four bonds and Te numbered by 2 has a dangling bond.

Our first-principles density-functional total-energy calculations indicate that both structures could exist. It is not clear which of the two structures should fit the HRTEM image of the DP twin shown in Fig. 1. Thus, the two structurally optimized models are used for HRTEM image simulations. The experimental parameters are obtained by through-focus and through-thickness simulations of the HRTEM image of the perfect regions near the boundary. We find that the defocus value is about $-65 \mathrm{~nm}$ and thickness is about $55 \mathrm{~nm}$. Figures 2(c) and 2(d) are the simulated images using the structural models of Figs. 2(a) and 2(b), respectively. For these simulations, the defocus value of $-65 \mathrm{~nm}$ and thickness of $55 \mathrm{~nm}$ are used. It is seen that Fig. 2(c) fits with Fig. 1 much better than Fig. 2(d). Thus, the combination of first-principles density- functional total-energy calculations and HRTEM image indicates that the GB1 structure shown in Fig. 2(a) is a convincing model for the GB that we have observed experimentally. However, it is noted that the GB2 structure may also be observed in CdTe. Thus, theoretically, we will consider both structures.
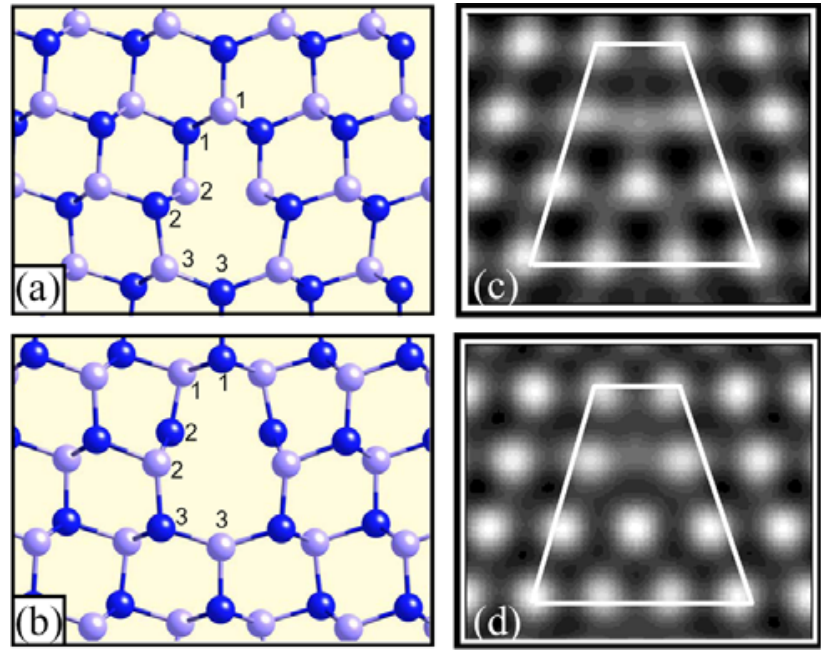

Fig. 2. (a) and (b) Determined atomic structure of GB1 and GB2. (c) and (d) Simulated HRTEM images of GB1 and GB2.
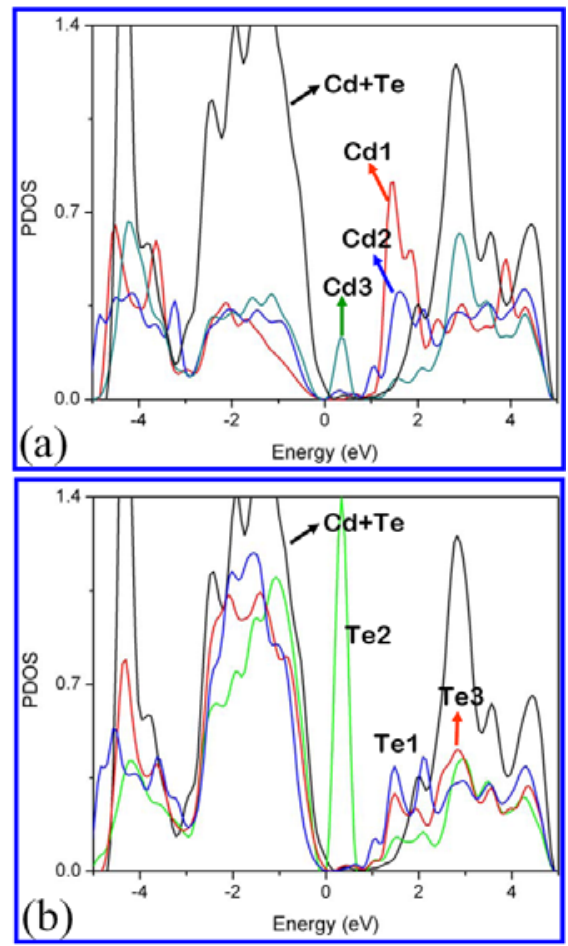

Fig. 3. Calculated PDOS of Cd and Te atoms around GB1.

To study the possible effects of the DP twin structures on the electronic property of CdTe, we calculate site- 
projected density of states (PDOS) of individual atoms around the boundaries and compare them with the PDOS of a $\mathrm{Cd}$ and Te pair in the perfect regions. Figure 3(a) shows the comparison of PDOS of the three $\mathrm{Cd}$ atoms on the GB1 shown in Fig. 2(a). The black solid line marked by $\mathrm{Cd}+\mathrm{Te}$ is the PDOS of the $\mathrm{Cd}$ and Te pair in the perfect region. The PDOS of the $\mathrm{Cd}$ atoms marked by number 1 , 2, and 3 in Fig. 2(a) are indicated by $\mathrm{Cd} 1, \mathrm{Cd} 2$, and $\mathrm{Cd} 3$, respectively. We see that the $\mathrm{Cd} 3$ atom produces a peak in the gap of CdTe. This is likely due to the fact that the $\mathrm{Cd} 3$ atom has a dangling bond. The rest of the $\mathrm{Cd}$ atoms are all four-fold and have no dangling bonds; thus, they do not produce deep levels in the gap.

Figure 3(b) shows the PDOS of the three Te atoms on the DP(1) boundary shown in Fig. 7(b) and a Cd and Te pair in a perfect region. The black solid line is the PDOS of the $\mathrm{Cd}$ and Te pair in the perfect region. The PDOS of the three Te atoms marked by numbers 1, 2, and 3 in Fig. 2(a) are indicated by $\mathrm{Te} 1, \mathrm{Te} 2$, and $\mathrm{Te} 3$, respectively. We see that the $\mathrm{Te} 2$ atom produces a very large peak in the gap region. This is because the Te2 atom has weak interaction with another Te atom.
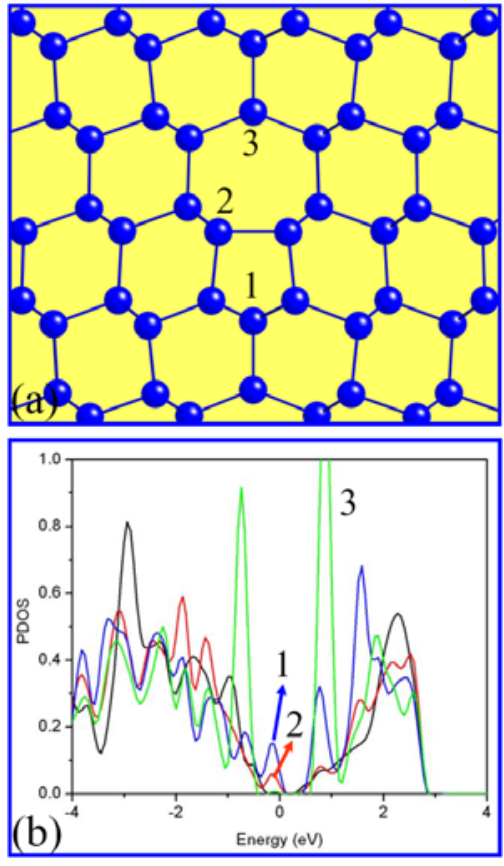

Fig. 4. (a) Atomic structure of GB in Si. (b) Calculated PDOS of Si atoms around the GB.

Figure 4(a) shows the GB structure in $\mathrm{Si}$ relaxed by density-functional theory. Compared to $\mathrm{Si}$ in perfect regions, Si1 has one extra bond, Si2 has wrong bonding angles, and Si3 has a dangling bond. Typically, the dangling bonds create deep-level states. However, our calculations revealed different results. Figure 4(b) shows the PDOS of the three Si atoms on the DP boundary and a $\mathrm{Si}$ atom in a perfect region. The black solid line is the PDOS of the $\mathrm{Si}$ in the perfect region. The PDOS of the three Si atoms marked by numbers 1, 2, and 3 in Fig. 4(a) are indicated by 1,2 , and 3 , respectively. Our results reveal that Si3 does not create deep levels. Instead, Si1 and $\mathrm{Si} 2$ create deep levels, as indicated by the arrows.

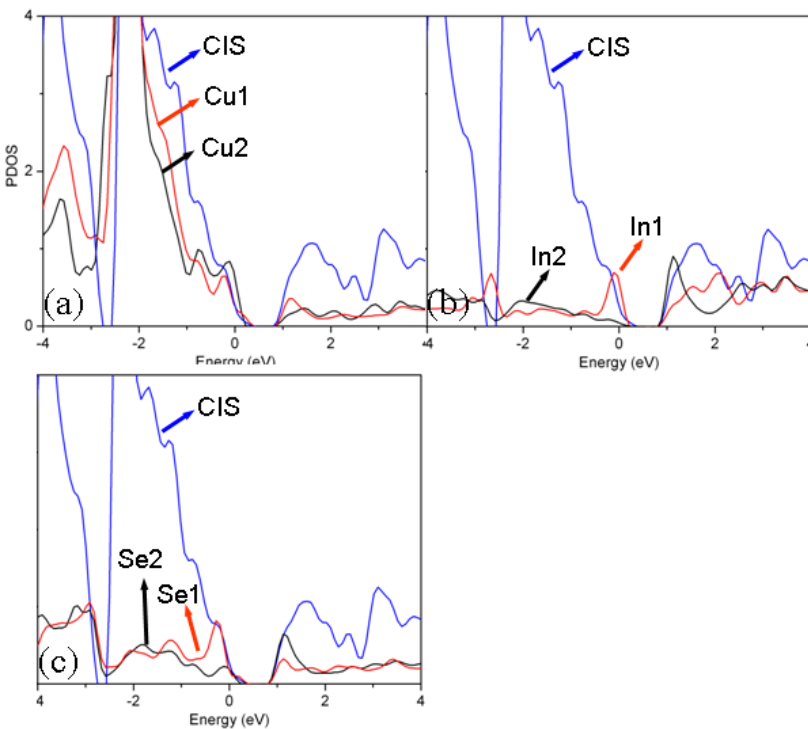

Fig. 5. Calculated PDOS of (a) Cu, (b) In, and (c) Se atoms around GB1 in CIS.

We have also adopted the GB structure for CIS. Surprisingly, however, they do not create deep levels in CulnSe $\mathrm{S}_{2}$. Figure 5 shows the calculated PDOS of (a) $\mathrm{Cu}$, (b) In, and (c) Se atoms around GB1 in CIS. It is seen that unlike the GBs in Si and CdTe, the GBs in CIS exhibit no deep levels. We found that the reason for this unusual behavior in CIS is due to the huge expansion around the boundary. Our results thus explain why Si and CdTe solar cells usually require special passivation, whereas CIS solar cells do not.
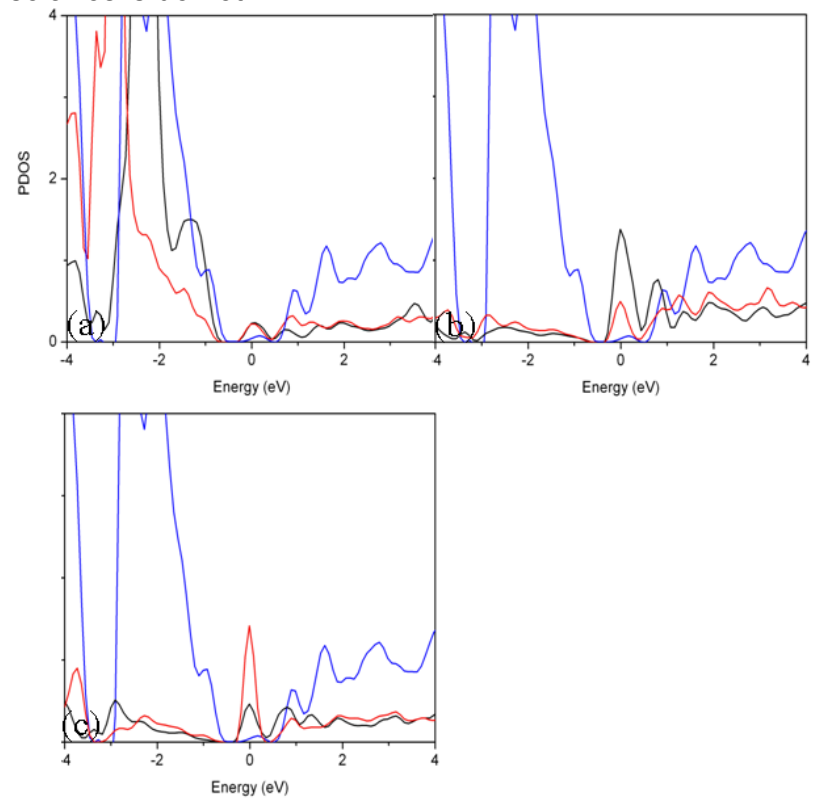

Fig. 6. Calculated PDOS of (a) $\mathrm{Cu}$, (b) In, and (c) Se atoms around GB1 in CIS without expansion. 
To demonstrate our explanation, we have calculated the PDOS of (a) Cu, (b) In, and (c) Se of GB1 without expansion (Fig. 6). It is seen that without expansion, the very same GB showed deep levels.

We further find that the presence of $\mathrm{Ga}$ can affect the behavior of GBs in CIS. Ga at some In sites are found to present deep levels. In addition, the Se atoms bonding to these $\mathrm{Ga}$ atoms are also affected.
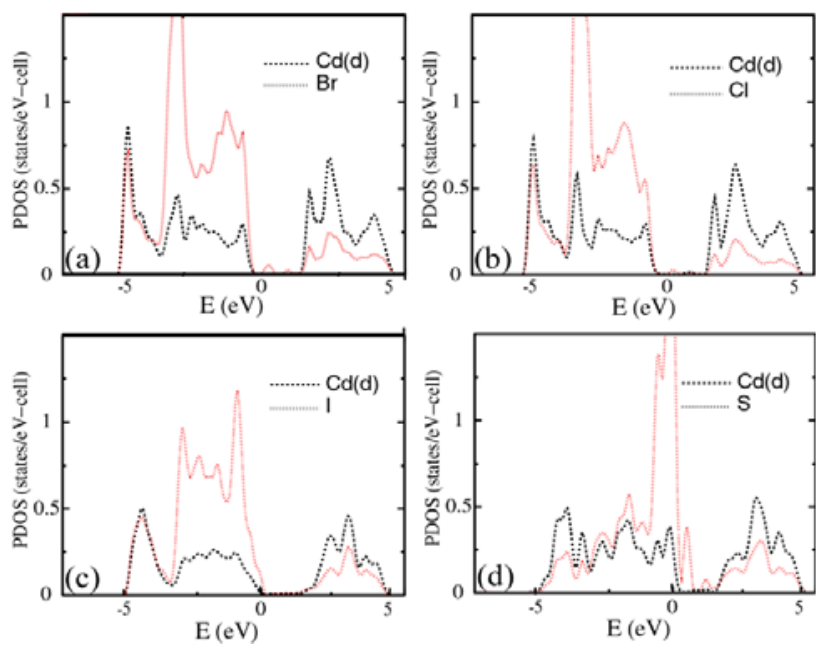

Fig. 7. Calculated PDOS of GB1 passivated by (a) Br, (b) $\mathrm{Cl}$, (c) I, and (d) S.

We now discuss how the GBs in Si and CdTe can be passivated. We find that hydrogen can passivate the dangling bond of $\mathrm{Si} 3$ in Fig. 4(a). However, this passivation does not affect $\mathrm{Si} 2$ and $\mathrm{Si} 3$ atoms. It interacts strongly with Si3.

It is believed that one of the effects of $\mathrm{CdCl}$ treatment is the passivation of defects by $\mathrm{Cl}$. In our calculations, in addition to $\mathrm{Cl}$, we also considered $\mathrm{S}$ and two other group$\mathrm{V}$ elements, $\mathrm{Br}$ and $\mathrm{I}$. Our total-energy calculations reveal that all these atoms are more favorable to bond with two $\mathrm{Cd}(1)$ atoms with dangling bonds, rather than to bond with Te atoms. To study the passivation effects of the GB1 by $\mathrm{Br}, \mathrm{Cl}, \mathrm{I}$, and $\mathrm{S}$, we calculate PDOS of individual atoms around the boundaries. Figure 7 shows the PDOS of a $\mathrm{Cd}(1)$ atom in the GB1 boundary after it is bonded with a $\mathrm{Br}, \mathrm{Cl}, \mathrm{I}$, or $\mathrm{S}$ atom (dashed line) and the PDOS of the $\mathrm{Br}$, $\mathrm{Cl}, \mathrm{I}$, and $\mathrm{S}$ atoms (dotted line). We see that the $\mathrm{Cd}(1)$ atom is no longer producing significant energy levels in the gap when $\mathrm{Cd}(1)$ atoms are bonded by the $\mathrm{Br}, \mathrm{Cl}, \mathrm{I}$, and $\mathrm{S}$ atoms. The $\mathrm{Br}, \mathrm{Cl}$, and I atoms themselves also do not produce significant peaks in the gap. These indicate that $\mathrm{Br}, \mathrm{Cl}, \mathrm{I}$, and $\mathrm{S}$ atoms can passivate well the $\mathrm{Cd}$ dangling bonds in the DP(1) twin boundaries. However, unlike $\mathrm{Br}$, $\mathrm{Cl}$, and I atoms, the $\mathrm{S}$ atom does not effectively passivate the Cd dangling bonds, as seen in Fig. 7(d), though the S atom bonds with the $\mathrm{Cd}$ atoms with dangling bonds. The $\mathrm{S}$ atom itself, as well as the $\mathrm{Cd}$ atom bonded by the $\mathrm{S}$ atom, produces high densities of energy levels in the bandgap.

\section{CONCLUSIONS}

We studied the atomic structure and electronic properties of GBs in polycrystalline photovoltaic materials such as $\mathrm{Si}$, CdTe, CIS, and CGS, using a combination of highresolution electron microscopy and first-principles calculations. We found that GBs in $\mathrm{Si}, \mathrm{CdTe}$, and CGS create deep levels, and belong to the conventional GB model (the "electronic model"). However, GBs in CIS do not create deep levels and therefore are electrically benign and do not exactly belong to the conventional GB model. Our study of GB passivation indicates that GBs in Si can only be partially passivated by $\mathrm{H}$. GBs in polycrystalline CdTe can be passivated well by $\mathrm{Cl}$ and I impurities.

\section{ACKNOWLEDGEMENTS}

This work was supported by the U.S. Department of Energy under Contract No. DE-AC36-99G010337. This research used resources of the National Energy Research Scientific Computing Center, which is supported by the Office of Science of the U.S. Department of Energy under Contract No. DE-AC02-05CH11231.

\section{REFERENCES}

[1] A. Rohatgi et al., Appl. Phys. Lett. 84, 145 (2004).

[2] X. Wu et al., Proc. $17^{\text {th }}$ European PVSEC, 2001, p.995.

[3] K. Ramanathan et al., Prog. Photovoltaics 11, 225 (2003).

[4] Proceedings of the $31^{\text {st }}$ IEEE Photovoltaic Specialists Conference (IEEE, New York, 2005).

[5] C.H. Champness, Proceedings $29^{\text {th }}$ IEEE Conference (IEEE, Piscataway, NY, 2002), p.732.

[6] J.Y.W. Seto, J. Appl. Phys. 46, 5247 (1975).

[7] C. Persson and A. Zunger, Phys. Rev. Lett. 91, 266401 (2003).

[8] C. Leendertz et al., Appl. Phys. Lett. 89, 113120 (2006).

[9] Y. Yan et al., Thin Solid Films 389, 75 (2001).

[10] Y. Yan et al., Phy. Rev. Lett. 99, 235504 (2007).

[11] G. Kresse and J. Hafner, Phys. Rev. B 47, 558 (1993).

[12] D. Vanderbilt, Phys. Rev. B 41, 7892 (1990).

[13] G. Kresse and J. Hafner, J. Phys.: Condens. Matter 6, 8245 (1994). 


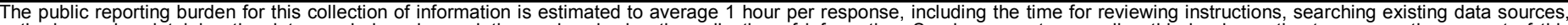

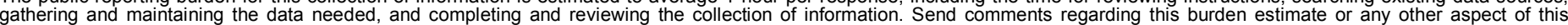

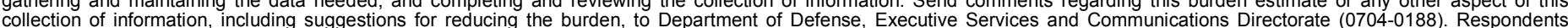

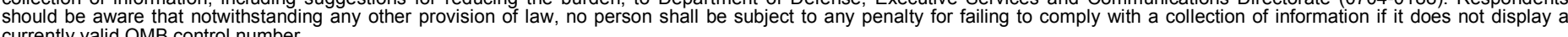

PLEASE DO NOT RETURN YOUR FORM TO THE ABOVE ORGANIZATION.

\section{REPORT DATE (DD-MM-YYYY) May 2008 \\ 2. REPORT TYPE Conference Paper}

\section{TITLE AND SUBTITLE}

Grain-Boundary Physics in Polycrystalline Photovoltaic Materials:

Preprint
3. DATES COVERED (From - To)

11-16 May 2008

5a. CONTRACT NUMBER

DE-AC36-99-G010337

5b. GRANT NUMBER

5c. PROGRAM ELEMENT NUMBER

5d. PROJECT NUMBER

NREL/CP-520-42510

5e. TASK NUMBER

PVA73201

5f. WORK UNIT NUMBER

7. PERFORMING ORGANIZATION NAME(S) AND ADDRESS(ES)

National Renewable Energy Laboratory

1617 Cole Blvd.

8. PERFORMING ORGANIZATION REPORT NUMBER

Golden, CO 80401-3393

NREL/CP-520-42510

9. SPONSORING/MONITORING AGENCY NAME(S) AND ADDRESS(ES)

10. SPONSOR/MONITOR'S ACRONYM(S) NREL

11. SPONSORING/MONITORING AGENCY REPORT NUMBER

12. DISTRIBUTION AVAILABILITY STATEMENT

National Technical Information Service

U.S. Department of Commerce

5285 Port Royal Road

Springfield, VA 22161

\section{SUPPLEMENTARY NOTES}

\section{ABSTRACT (Maximum 200 Words)}

We use the combination of high-resolution electron microscopy and density-functional theory to study the atomic structure and electronic effects of grain boundaries in polycrystalline photovoltaic materials such as Si, CdTe, CulnSe2, and CuGaSe2. We find that grain boundaries containing dislocation cores create deep levels in Si, CdTe, and CuGaSe2. Surprisingly, however, they do not create deep levels in CulnSe2. We further find that the presence of $\mathrm{Ga}$ in grain boundaries in CulnSe2 generates deep levels. These results may explain the fact that Si and CdTe solar cells usually require special passivation, whereas CulnSe2 solar cells do not. The passivation of grain boundaries in $\mathrm{Si}$ and $\mathrm{CdTe}$ is also studied. We find that grain boundaries in $\mathrm{CdTe}$ can be passivated very well by $\mathrm{Cl}, \mathrm{Br}$, and I.

15. SUBJECT TERMS

PV; grain boundary; large-area; transmission electron microscopy; polycrystalline; atomic structure; electronic properites; impurity;

\begin{tabular}{|l|l|l|l|l|}
\hline \multicolumn{2}{|l|}{ 16. SECURITY CLASSIFICATION OF: } & $\begin{array}{c}\text { 17. } \text { LIMITATION } \\
\text { OF ABSTRACT }\end{array}$ & $\begin{array}{c}\text { 18. NUMBER } \\
\text { OF PAGES }\end{array}$ \\
\hline $\begin{array}{l}\text { a. REPORT } \\
\text { Unclassified }\end{array}$ & $\begin{array}{c}\text { b. ABSTRACT } \\
\text { Unclassified }\end{array}$ & $\begin{array}{c}\text { c. THIS PAGE } \\
\text { Unclassified }\end{array}$ & $\begin{array}{c}\text { UL } \\
\end{array}$ &
\end{tabular}

19a. NAME OF RESPONSIBLE PERSON

19b. TELEPHONE NUMBER (Include area code) 